\title{
Bisphosphonate-related osteonecrosis of jaw (BRONJ): diagnostic criteria and possible pathogenic mechanisms of an unexpected anti-angiogenic side effect
}

\author{
Vascular Cell 5:1 I DOI: 10.1186/2045-824X-5-1 ～～C Li et al.; licensee Publiverse Online S.R.L. 2013 \\ Received: 12 Sep 2012 | Accepted: 10 Sep 2012 | Published: 14 Sep 2013 \\ Sharma Dileep, Ivanovski Saso, Slevin Mark, Hamlet Stephen, Pop Tudor S, Brinzaniuc Klara, \\ Petcu Eugen B ${ }^{@}$, Miroiu Rodica I \\ ${ }^{+}$Contributed equally ${ }^{@}$ Corresponding author
}

\begin{abstract}
Recently, bisphosphonates (BPs) have been widely used in medical practice as anti-resorptive agents owing to their anti-osteoclatic action. In addition, these compounds are also used for their analgesic action and their potential antitumour effect. Patients treated with BPs may subsequently develop osteonecrosis of the jaw or maxillary bone after minor local trauma including dental work, recently labelled as bisphosphonate osteonecrosis of jaw (BRONJ). However, the etiopathogenic mechanisms of this pathological condition are poorly understood. Although, several pathways have been proposed for BRONJ occurrence, no single model can explain all morphological changes observed at the macro- and microscopic level. Recent research suggests that BPs may promote an anti-angiogenic effect which contributes directly to the clinical features associated with BRONJ. Remarkably, the anti-angiogenic effect promoting BRONJ might be in keeping with the anti-neoplastic action of BPs. The current review, presents clinical diagnostic criteria. In addition, based on our own experience we describe the histopathological criteria for diagnosis of BRONJ and the possible pathways which may lead to this frustrating pathological condition.
\end{abstract}

\section{Introduction}

Bisphosphonates (BPs) are a group of pharmacological agents used as anti-osteoclastic, anti- resorptive agents in calcium metabolism disorders such as osteoporosis, multiple myeloma, Paget's disease and hypercalcemia of malignancy [1]. The primary objectives of administering these drugs are to improve bone morphology, prevent bone destruction and pathologic fractures, and reduce pain associated with the metastatic bone disease whilst decelerating bone resorption [ 2-4]. Interestingly, BPs resist hydrolysis in the gut and possess an anti-resorptive action inhibiting hydroxyapatite dissolution [ 5,6]. Licata et al. (2005) and Michaelson et al. (2005) have noted that the most important effect of these pharmacological agents is represented by promoting apoptosis in osteoclasts [ 7,8$]$.

Chemically, BPs represent pyrophosphate analogs possessing two variable regions, $\mathrm{R}_{1}$ and $\mathrm{R}_{2}$ on the carbon atom of BPs molecule attached to basic P-C-P structure. This allows variations in molecular structure and a range of potency corresponding to the changes in the structure [9]. The group occupying $\mathrm{R}_{1}$ position, usually hydroxyl, enhances the molecule's affinity to bone (calcium crystals) and the variable group at $\mathrm{R}_{2}$ position decides its anti-resorptive action, specifically its potency and efficacy [9].

Classically, BPs have been classified into: non-nitrogen containing BPs (NNBP) and nitrogen containing BPs (NBP) depending on the presence or absence of nitrogen in their $\mathrm{R}_{2}$ group. However, Russell et al. [ 10] further divided the NBPs into Alkyl-amino and Heterocyclic NBPs based on the mode of action (Table 1).

Table 1

$<$ bold $>$ Bisphosphonates: types and mode of action $<$ bold $>$

\begin{tabular}{|c|c|c|c|}
\hline Generation & Type & Examples & Mode of action \\
\hline First & NNBPs & $\begin{array}{l}\text { Etidronate } \\
\text { Clodronate } \\
\text { Tiludronate }\end{array}$ & $\begin{array}{l}\text { Formation of an ATP derivative that impairs osteoclast function and } \\
\text { induces osteoclastic apoptosis }\end{array}$ \\
\hline Second & Alkyl-amino & Pamidronate & Inhibits sterol synthesis via the mevalonate pathway specifically \\
\hline
\end{tabular}




\begin{tabular}{l|l|l|l}
\hline Generation & \multicolumn{1}{|c|}{ Type } & Examples & \multicolumn{1}{c}{ Mode of action } \\
\hline & NBPs & $\begin{array}{l}\text { Alendronate } \\
\text { Ibandronate } \\
\text { Olpadronate }\end{array}$ & inhibiting its Farnesyl pyrophosphate synthase (FPPS) enzyme \\
& & Reterocyclic & Risedronate \\
Third & NBPs & Inhibits FPPS enzyme and stabilize conformational changes \\
& & Zoledronate & \\
\hline
\end{tabular}

Clinically, both the NNBPs and NBPs are used as antiresorptive agents (Table 2) but the NNBP are known to be less potent and thus are mainly used in management of osteoporosis where as the heterocyclic NBPs are the most potent BPs used in severe bone resorption cases like in malignancies (Table 2).

Table 2

$<$ bold $>$ Bisphosphonates: potency, administration and main indications $<$ /bold $>$

\begin{tabular}{|c|c|c|c|}
\hline $\begin{array}{l}\text { Type of } \\
\text { BPs }\end{array}$ & Potency & Administration & Main Indications \\
\hline \multicolumn{4}{|l|}{ NNBPs } \\
\hline Etidronate & 1 & Oral & Osteoporosis, Paget's disease of bone \\
\hline Clodronate & 10 & $\begin{array}{l}\text { Oral/ } \\
\text { Intravenous }\end{array}$ & Osteoporosis, Paget's disease of bone \\
\hline Tiludronate & 10 & Oral & Paget's disease of bone \\
\hline \multicolumn{4}{|l|}{ NBPs } \\
\hline Pamidronate & 100 & Intravenous & $\begin{array}{l}\text { Osteolytic bone metastases of breast cancer and osteolytic lesions of } \\
\text { multiple myeloma, Paget's disease of bone }\end{array}$ \\
\hline Alendonate & 500 & Oral & Osteoporosis, Paget's disease of bone \\
\hline Ibandronate & 1000 & $\begin{array}{l}\text { Oral, } \\
\text { Intravenous }\end{array}$ & Osteoporosis \\
\hline Risedronate & 2000 & $\begin{array}{l}\text { Oral, } \\
\text { Intravenous }\end{array}$ & $\begin{array}{l}\text { Osteoporosis, Paget's disease of bone, osteolytic lesions of multiple } \\
\text { myeloma, hypercalcemia of malignancy }\end{array}$ \\
\hline Zoledronate & 10000 & Intravenous & $\begin{array}{l}\text { Osteolytic lesions of multiple myeloma and metastases from solid } \\
\text { tumors, hypercalcemia of malignancy }\end{array}$ \\
\hline
\end{tabular}

BPs: side-effects

Orally administered BPs may induce recurrent ulcers with burning sensation and blisters in the oral cavity, erosive oesophagitis, oesophagal stenosis, uveitis, gastric ulcerations and abdominal pain [ 11- 13]. However, more serious effects such as bisphosphonate-related osteonecrosis of jaw (BRONJ), is seen most commonly after intravenous NBPs such as pamidronate and zoledronate [14].

\section{BRONJ: epidemiological trends}

The first clinical description of BRONJ by Marx et al. (2003) ushered several reports from all across the world where BPs are used [ 15]. In general, intravenous nitrogen containing BPs shows higher incidence of BRONJ but a large variation ranging from $0.0 \%$ to $28 \%$ has been reported [ 16-18] depending upon the specific type of BPs used, single or multiple BPs used concomitantly or sequentially, duration of therapy and the condition for which BPs were administered. In addition oral BPs have also been associated with BRONJ, although at much lower percentage, not more that $4 \%[19,20]$.

\section{BRONJ: clinical diagnostic criteria}

In 2007, the American Association of Oral and Maxillofacial Surgeons and the American Society for Bone and Mineral Research described BRONJ as an area of exposed bone in the maxillofacial region in a patient on BPs or who has taken in the past these pharmacological agents, without any history of radiotherapy. Furthermore, the lesions must not be healed within 8 weeks after identification by a healthcare practitioner to qualify as a BRONJ case [ 21, 22]. Recently, it was reported a clinical variant of BRONJ that lacked bone exposure, albeit fulfilling all other essential criteria for BRONJ [ 23, 24]. This warrants the addition of various other clinical signs and symptoms into the diagnostic criteria (Table 3).

Table 3 


\begin{tabular}{l|l}
\hline Exposed necrotic jaw bone & Pain in tooth or bone \\
& Suppuration \\
Swelling \\
Sinus and fistula related to jaw bone \\
Mobility of teeth \\
& Trismus \\
& Non-healing extraction sockets \\
& Soft tissue ulcerations \\
& Gross mandibular deformity \\
& Sequestration of bone \\
\hline
\end{tabular}

BRONJ: clinical signs and symptoms

A careful application of these criteria is of paramount importance as other intraoral conditions such as gingivitis and periodontal disease, mucositis, periapical lesions due to pulpal infection and resulting osteomyelitis, sinusitis, bone tumours (primary and metastasic) and osteoradionecrosis need to be ruled out.

\section{BRONJ- histopathological diagnostic criteria}

As other types of osteonecrosis determined by different etiologies, BRONJ is characterized by the presence of osteocyte-depleted bone lacunae. Our diagnostic experience suggests that this avascular necrosis is characterized by lacunae osteocyte depletion which is more obvious in the deeper layers of the bone while the lacunae located towards the surface of the bone lamellae will lose the osteocytes at a later stage (Figure 1).

\section{Figure 1}

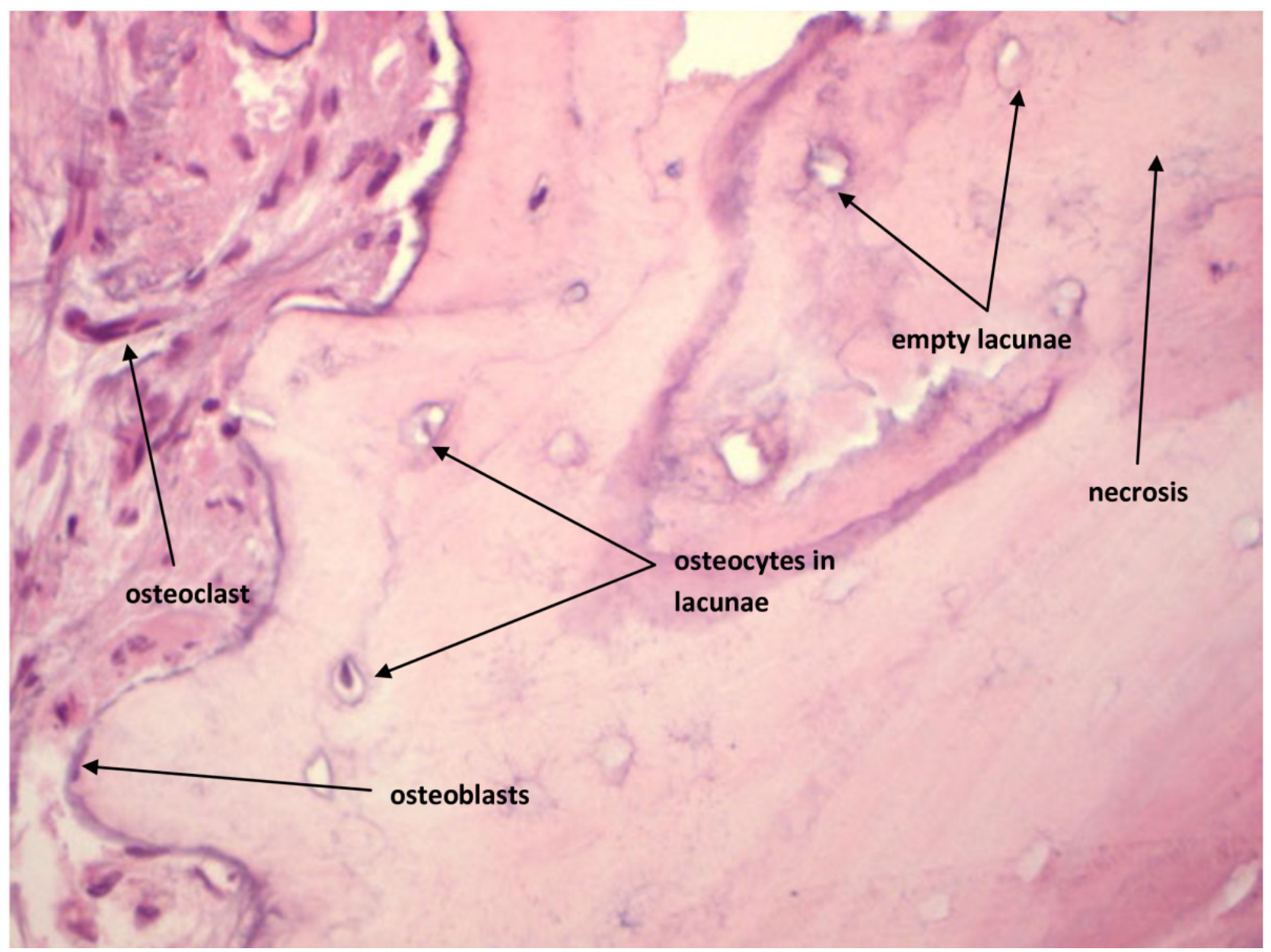

BRONJ: Empty lacunae are seen in the centre of the bone while towards the surface some lacunae display their osteocytes

The associated morphological features of this specific type of avascular necrosis are quite heterogeneous. Some areas of the affected bone with show extensive haemorrhage associated with massive chronic inflammatory cells infiltrate represented by lymphocytes and plasma cells which is best observed towards the surface of the bone (Figures 2,3). In addition, a significant number of these cells are osteoclasts which continue to exert their characteristic bone resorptive action in parallel with the on-going lacunar depletion of osteocytes (Figure 4). 


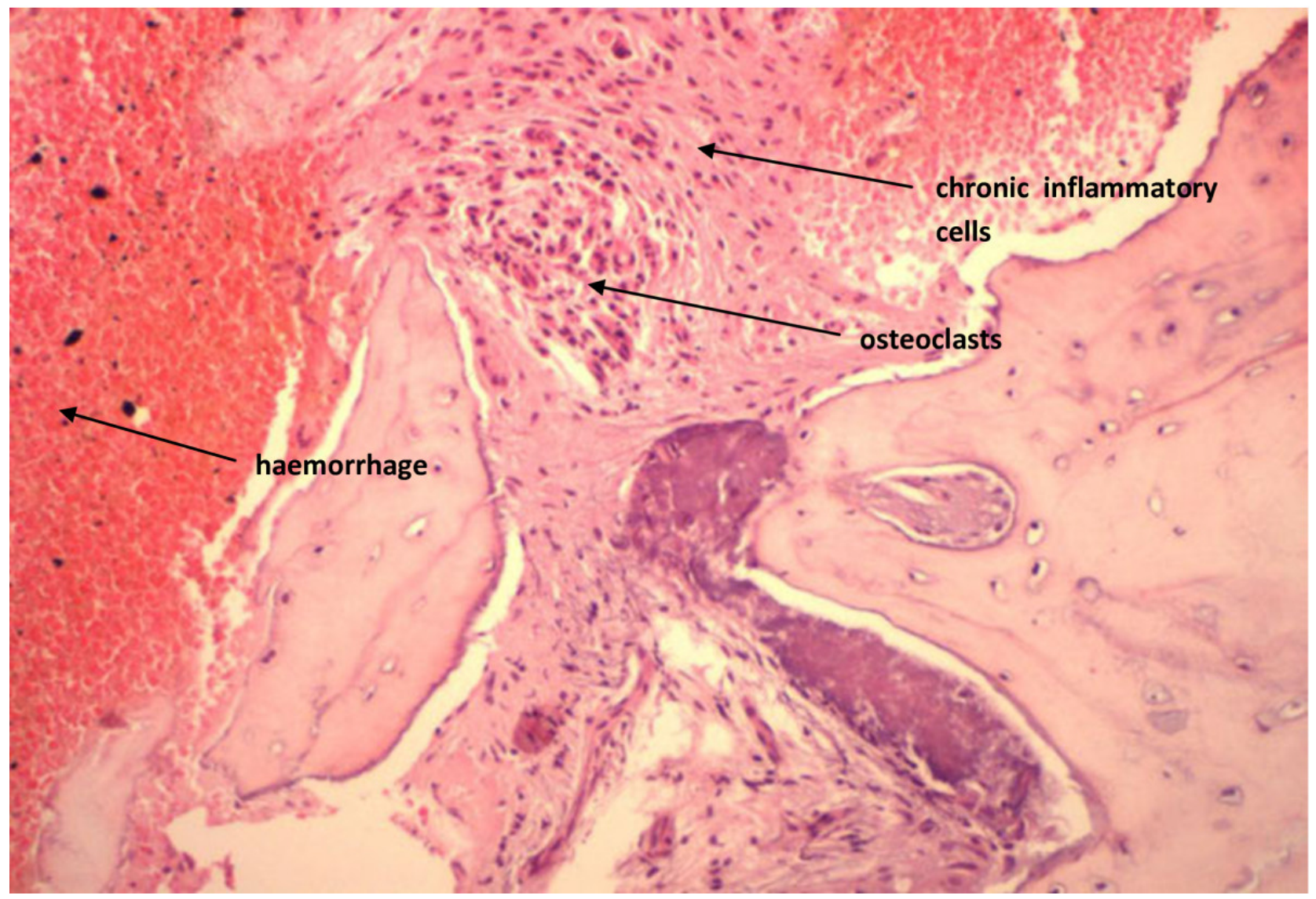

BRONJ: Haemorrhage and chronic inflammatory cells infiltrate

Figure 3

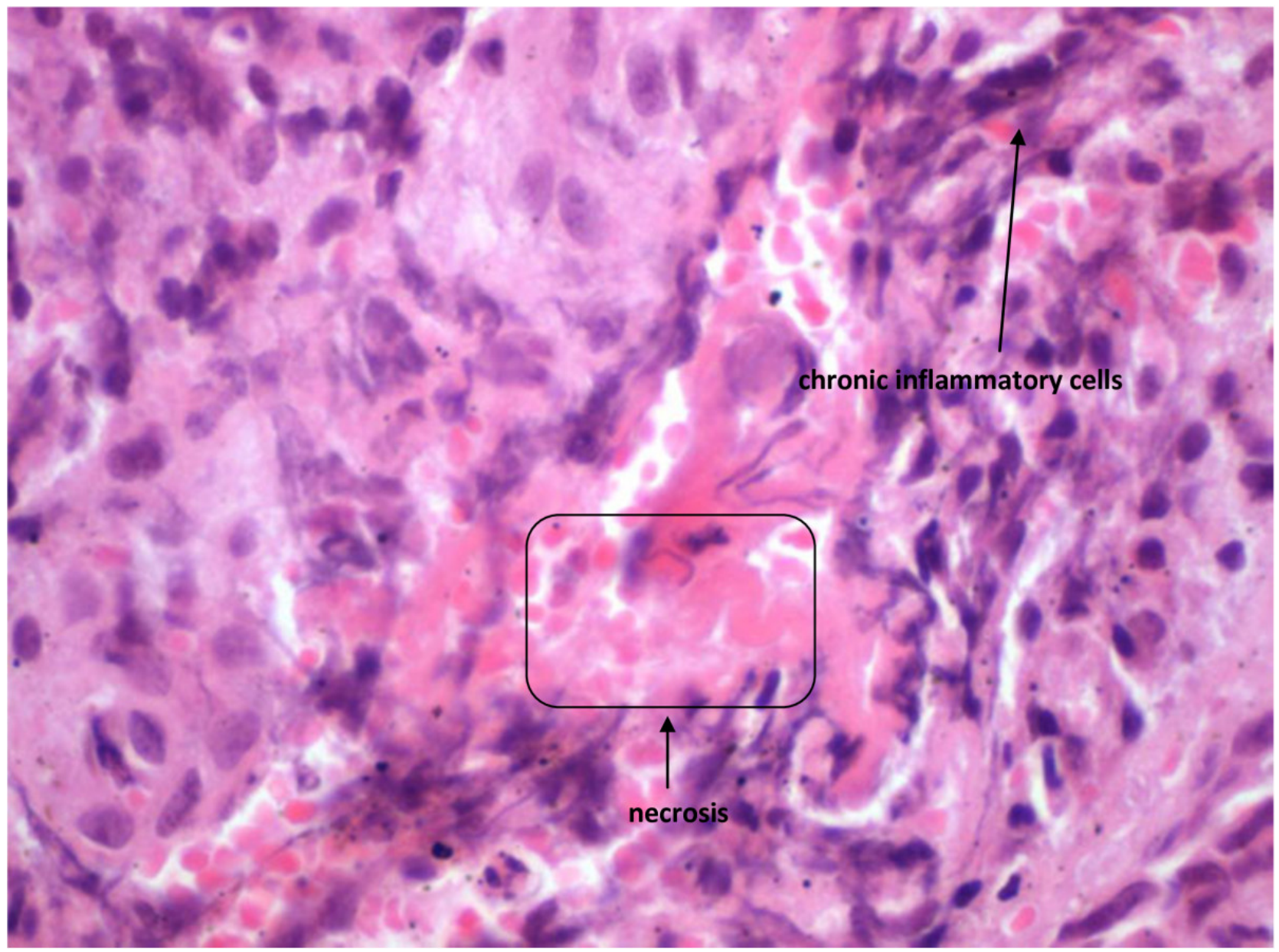

BRONJ: Chronic inflammatory cells infiltrate 


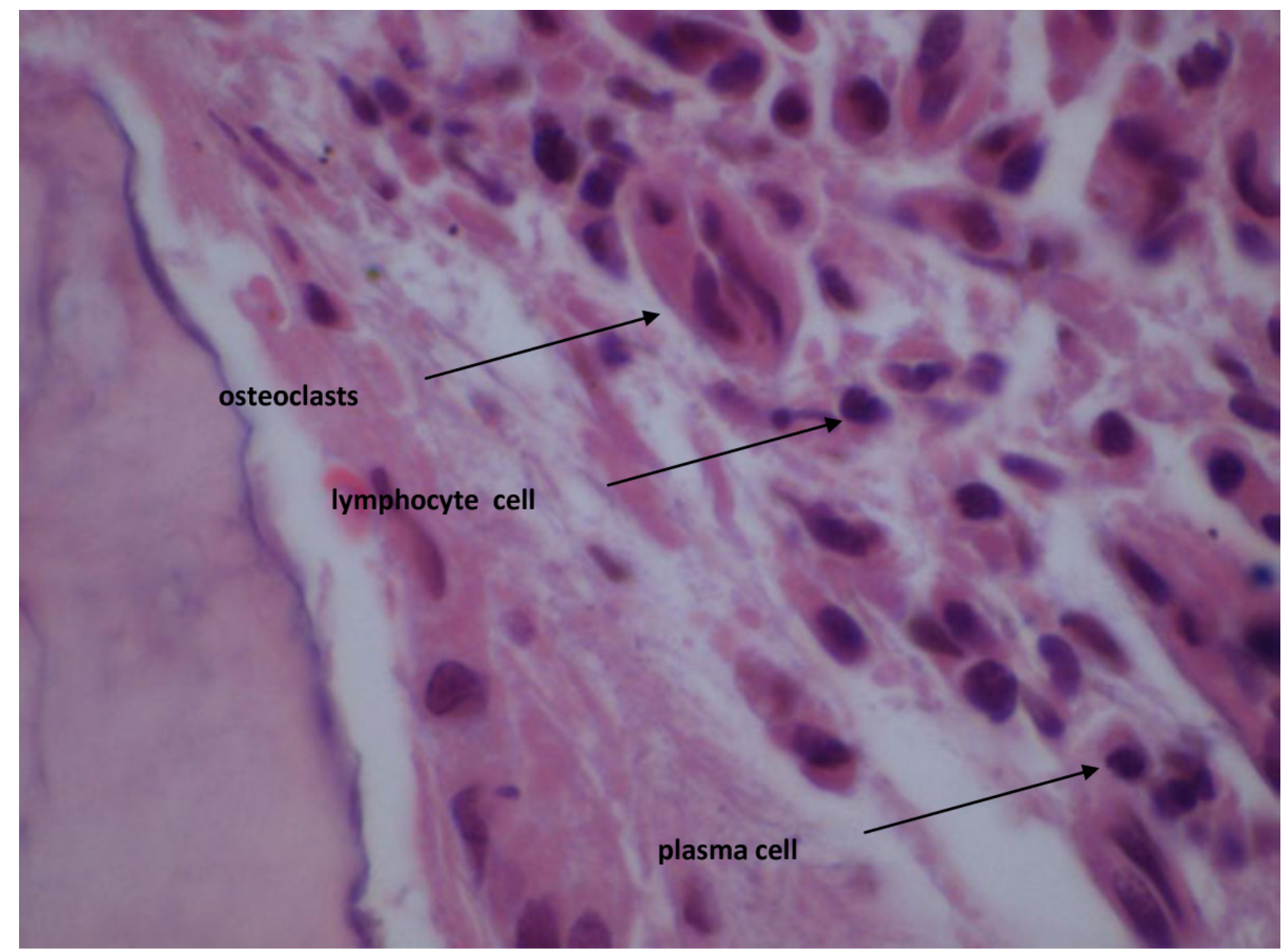

BRONJ: Osteoclasts, lymphocytes and plasma cells

\section{BRONJ: the anti-angiogenic side effect of BPs treatment}

It is known that angiogenesis or formation of new immature blood capillaries is an essential factor in healing of wounds as well as invasion of normal tissues by malignant cells [ 25]. Also, normal vascularization represents an essential requirement for tissue homeostasis, local immunity and adequate regeneration or repair of all vital tissues of the body, more so in case of bone due to its high turnover rate. In a recent study by Wehrhan et al. (2011), mucoperiosteal tissue samples from BRONJ cases and controls were assessed for vascularization with CD31 staining and neo-angiogenesis by CD105 evaluation. It was reported that although there was no difference in vascularization between sample groups, there were significantly fewer CD105-positive vessels in BRONJ samples suggesting that neo-angiogenesis was suppressed in BRONJ cases [ 26].

Vascular endothelial growth factor (VEGF), in circulation as well as local VEGF mRNA expression, is considered a classic parameter of angiogenesis. Remarkably, in non-small cell lung cancer cell lines, zoledronic acid promotes a significant reduction in mRNA and protein expression of VEGF [ 27]. Moreover, serum VEGF levels and other cytokines involved in angiogenesis such as interleukin-17, have also been found to decrease after administration of zoledronate or pamidronate [ 28- 30]. It is very important to note that BPs determine an efficient decrease of VEGF at 24 hours after administration. The VEGF drop is sustained and it has been noted at 7 days after pamidronate infusion and at 21 days post zoledronate administration [ 28-30].

Although, there are no studies evaluating the duration of anti-VEGF effect after BPs treatment, it might be possible to be time limited. In vitro and in vivo experiments have revealed that clodronate is an efficient anti-angiogenic agent. The clodronate-related anti-angiogenesis seems to be related to its direct inhibitory action on endothelial cell proliferative activity coupled with inhibition of powerful pro-angiogenic factors such as fibroblast-growth factor 2 (FGF2) [ 31].

Other authors have reported that NBPs have a significant anti-angiogenic effect inhibiting human umbilical vein endothelial cells (HUVEC) proliferation, adhesion, survival, migration and actin stress fiber formation by interfering with protein prenylation [ 32,33]. More importantly, these studies have revealed that NBPs such as zoledronic acid inhibit endothelial cells function and survival by acting on ERK1/2, JNK, Rock, FAK and PKB in a prenylation dependent reaction [ 32]. Recent studies performed on human breast cancer cell lines suggest that pamidronate and clodronate have a robust anti-angiogenic action on the HIF-1alpha/VEGF axis via inhibition of the PI-

3K/AKT/mTOR signaling pathways. In addition, both agents inhibit the pro-angiogenic action of IGF-1 on breast cancer cells lines [ 34]. It is noteworthy to mention that the anti-angiogenic effect of BPs may be explained by their inhibition of the endothelial progenitor cell differentiation. Studies conducted in vitro have shown that at low doses, zoledronic acid inhibits the differentiation of endothelial progenitor cells while at high doses it will induce apoptosis 


\section{Figure 5}
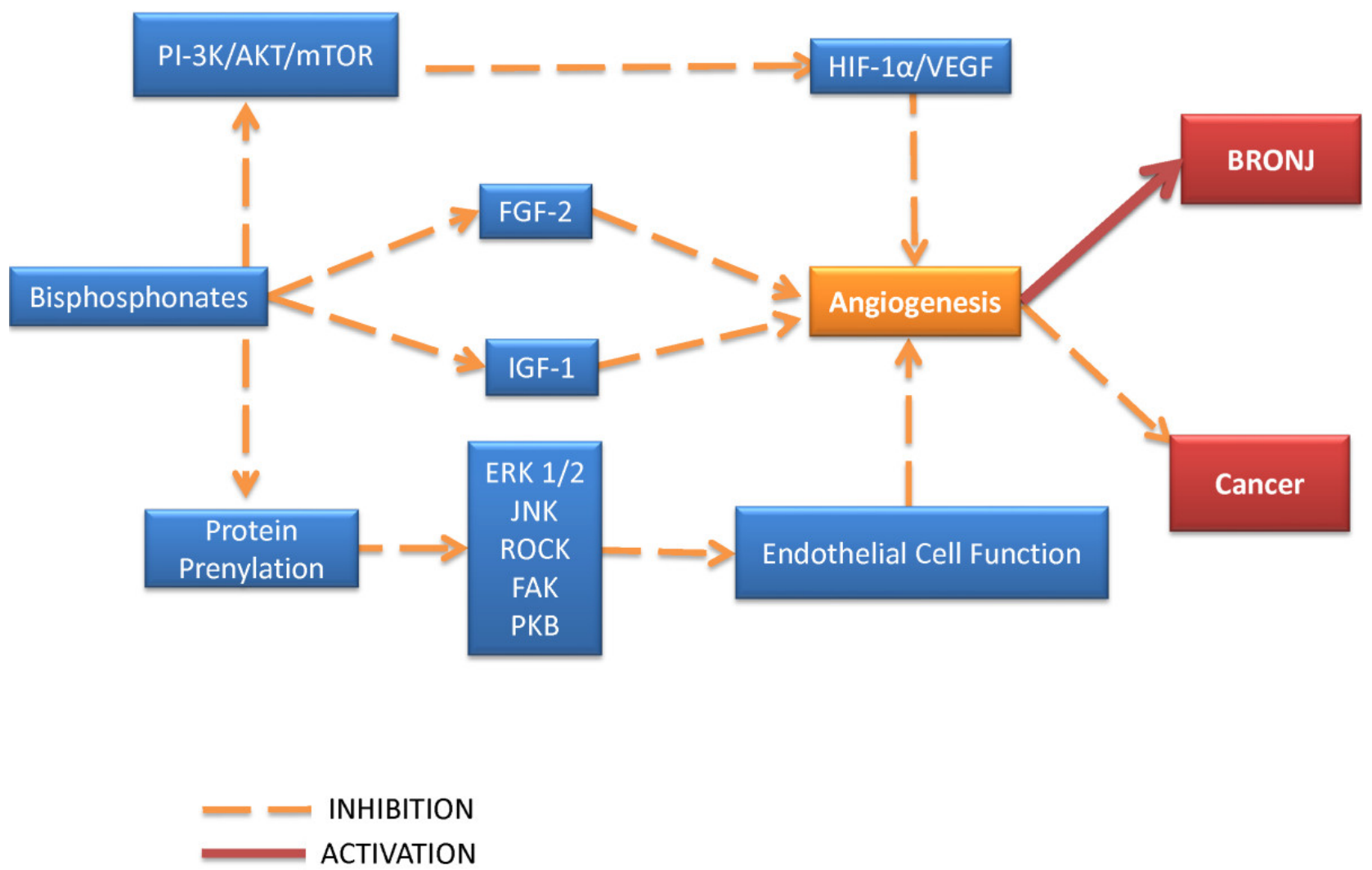

Bisphosphonates: mechanisms of anti-angiogenesis

Our own histological evaluation of patients treated with BPs has confirmed that BRONJ represents an avascular process of necrosis of the jaw bone due to the lack of blood vessels in the necrotic areas paradoxically associated with an on-going bone resorptive action induced by osteoclasts. However, numerous studies have revealed that bisphosphonates inhibit the osteoclasts by preventing their differentiation from their marrow precursors or inhibiting the mevalonate pathway which is crucial for their functionality [ 36, 37]. Therefore, the presence of multinucleated giant cells osteoclasts in BRONJ patients is puzzling. As mentioned before, we have been able to observe routinely osteoclasts in histological slides prepared with tissue removed from the lesional and peri-lesional BRONJ area. This suggests that the anti- osteoclastic action of BPs could be limited and once they re-appear in the bone, the destruction is increased. More importantly, it is likely that the anti-osteoclastic and the anti- angiogenic action of BPs are not achieved through the same pathway but their final effect is summative in producing BRONJ.

Closely related to their anti-angiogenic effect, the BPs may affect the soft tissue structures seen in the immediate vicinity of the jaw or maxillary bone, potentially creating a vicious circle whereby the anti-angiogenesis is enhanced and complicated by soft tissue cells damage.

In studies with oral keratinocyte/model, BPs were shown to induce senescence, apoptosis and inhibition of cell growth by blocking FPPS enzyme of cholesterol biosynthetic pathway [ 38-43] which probably indirectly interfere with the blood supply of the bone. This is the same molecular mechanism through which NBPs inhibit osteoclast function, promoting apoptosis and preventing invasion of tumor cells (Figure 6).

\section{Figure 6}



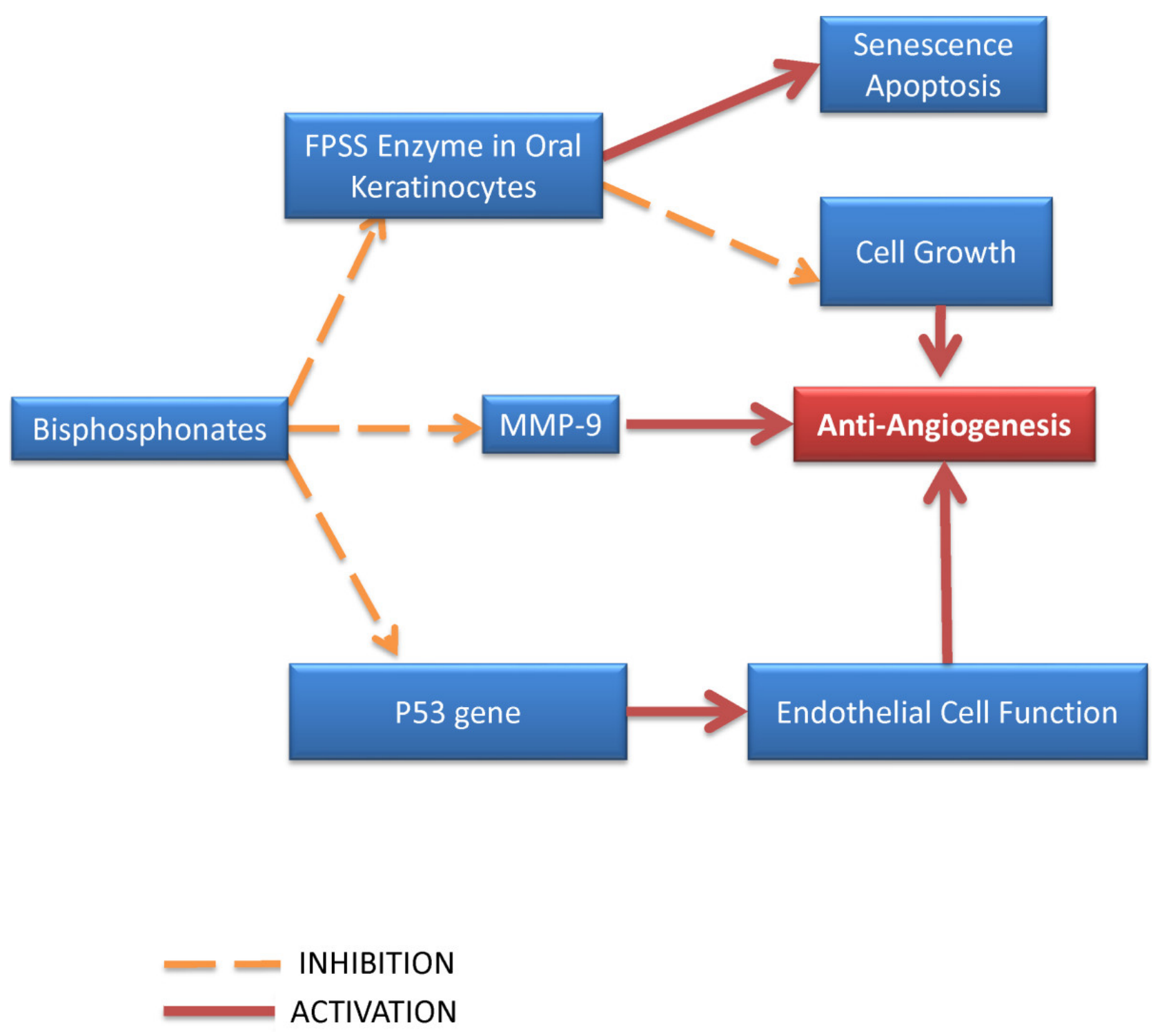

Bisphosphonate effects on oral keratinocytes

A histological evaluation of BRONJ has revealed a reduced p53 gene expression of tissue samples via mevalonate pathway which results in a reduced numbers of basal epithelial progenitor cells which could result in an impaired healing capacity of oral mucosa [44]. An immunohistochemical study conducted on dogs has shown that MMP-9, a factor of paramount importance for the extracellular matrix homeostasis, is significantly decreased in subjects treated with zoledronic acid, suggesting that BPs promote epithelial cell apoptosis [ 45] (Figure 6). All of the above mentioned abnormalities may in fact be at work in BPs treated patients and they may act in concert to promote extensive bone destruction as seen in BRONJ.

However, recent studies have revealed that the reduced migration ability of various cell types of hard and soft tissues such as bisphosphonate-treated human umbilical cord vein endothelial cells (HUVEC), fibroblasts (normally a source of pro-angiogenic factors) and osteogenic cells may be potentially prevented by administration of factors with anti-BPs action. Some authors have claimed that the mevalonate pathway metabolite, geranylgeraniol $(\mathrm{GGOH})$ or naturally occurring farnesol could an anti-BPs effect healing the lesions seen in BRONJ [ 46, 47]. Therefore, these factors may represent the basis for a potential curative therapeutic protocol in BRONJ patients but more validation studies are necessary before a pilot study could be implemented [ 46,47$]$.

Clearly bisphosphonates have a demonstrated multimodal ability to interfere with normal angiogenesis. Given the critical role of vasculature development in tissues and in particular bone, where the turnover rate is markedly higher than in other tissues, this represents a potential process that may therefore be intimately associated with the development of necrotic bone conditions such as that seen in the oral maxillofacial area of patients on high potency bisphosphonates following routine dental procedures.This research is in compliance with the Helsinki Declaration. Approval has been obtained from Griffith University Human Research Ethics Committee. Written informed consent was obtained from the patient for publication of this report and any accompanying images.

\section{Declarations}

\section{Authors' original submitted files for images}

Below are the links to the authors' original submitted files for images. 
Authors' original file for figure 1

Authors' original file for figure 2

Authors' original file for figure 3

Authors' original file for figure 4

Authors' original file for figure 5

Authors' original file for figure 6

Authors' original file for figure 7

Authors' original file for figure 8

Authors' original file for figure 9

\section{Competing interests}

The authors declare that they have no competing interests.

\section{Authors' contributions}

DS: drafted part of the manuscript including the digital graphics, performed the literature search, assisted the histopathological selection, SI: designed the project, drafted part of the manuscript including the digital graphics, provided clinical feed-back, analysis and interpretation and supervised DS, MS: provided histopathological research information and evaluation, helped drafting the manuscript, $\mathrm{SH}$ : provided histopathological analysis, experimental research information and evaluation, helped drafting the manuscript, TSP: helped drafting the manuscript, provided research and clinical interpretation , performed digital imaging processing, KB: helped drafting the manuscript, provided basic research information and histopathological evaluation, EBP: drafted part of the manuscript, performed histopathological selection, processing and evaluation, experiential data interpretation, designed the project and supervised DS, RIM: designed the project, drafted the manuscript, provided clinical background and analysis, performed the literature search, evaluated experimental data and digital imaging processing. All authors read and approved the final manuscript.

\section{References}

1. Fleisch H. Bisphosphonates: mechanisms of action. Endocr Rev. 1998;19:80-100. View Article Google Scholar

2. Reid IR, Miller P, Lyles K, Fraser W, Brown JP, Saidi Y, Mesenbrink P, Su G, Pak J, Zelenakas K, Luchi M, Richardson P, Hosking D. Comparison of a single infusion of zoledronic acid with risedronate for Paget's disease. N Engl J Med. 2005;353:898-908.

View Article Google Scholar

3. Hillner BE, Ingle JN, Berenson JR, Janjan NA, Albain KS, Lipton A, Yee G, Biermann JS, Chlebowski RT, Pfister DG. American society of clinical oncology guideline on the role of bisphosphonates in breast cancer. American society of clinical oncology bisphosphonates expert panel. J Clin Oncol. 2000;18:1378-1391.

View Article Google Scholar

4. Petcu EB, Schug SA, Smith H. Clinical evaluation of onset of analgesia using intravenous pamidronate in metastatic bone pain. J Pain Symptom Manage. 2002;24:281-284.

View Article Google Scholar

5. Blomen LJMJ. History of the bisphosphonates: discovery and history of the non-medical uses of bisphosphonates. Bisphosphonates on bones. 1995;:111-124.

View Article Google Scholar

6. Fleisch H, Russell RGG, Francis MD. Diphosphonates inhibit hydroxyapatite dissolution and bone resorption in tissue culture and . Science. 1969;165:1262-1264.

View Article Google Scholar

7. Licata AA. Discovery, clinical development, and therapeutic uses of bisphosphonates. Ann Pharmacother. 2005;39:668-677.

View Article Google Scholar 
8. Michaelson MD, Smith MR. Bisphosphonates for treatment and prevention of bone metastases. J Clin Oncol. 2005;23:8219-8224.

View Article Google Scholar

9. Papapoulos SE. Bisphosphonates: how do they work?. Best Pract Res Clin Endocrinol Metab. 2008;22:831-847.

View Article Google Scholar

10. Russell RGG, Watts NB, Ebetino FH, Rogers MJ. Mechanisms of action of bisphosphonates: similarities and differences and their potential influence on clinical efficacy. Osteoporos Int. 2008;19:733-759. View Article Google Scholar

11. Kharazmi M, Persson U, Warfvinge G. Pharmacovigilance of oral bisphosphonates: adverse effects manifesting in the soft tissue of the oral cavity. J Oral Maxillofac Surg. 2012;70:2793-2797.

View Article Google Scholar

12. Lanza FL, Hunt RH, Thomson AB, Provenza JM, Blank MA. Endoscopic comparison of esophageal and gastroduodenal effects of risedronate and alendronate in postmenopausal women. Gastroenterology. 2000;119:631-638.

View Article Google Scholar

13. Abraham SC, Cruz-Correa M, Lee LA, Yardley JH, Wu TT. Alendronate-associated esophageal injury: pathologic and endoscopic features. Mod Pathol. 1999;12:1152-1157.

View Article Google Scholar

14. Fortuna G, Ruoppo E, Pollio A, Aria M, Adamo D, Leuci S, Orabona GD, Mignogna MD. Multiple myeloma vs. breast cancer patients with bisphosphonates-related osteonecrosis of the jaws: a comparative analysis of response to treatment and predictors of outcome. J Oral Pathol Med. 2012;41:222-228.

View Article Google Scholar

15. Marx RE. Pamidronate (Aredia) and zoledronate (Zometa) induced avascular necrosis of the jaws: a growing epidemic. J Oral Maxillofac Surg. 2003;61:1115-1117.

View Article Google Scholar

16. Bianchi ML, Limonta C, Frasunkiewicz J, Biggioggero M, Vai S. Comment on: Bisphosphonates and osteonecrosis of the jaw. Rheumatology (Oxford). 2008;47:383-.

View Article Google Scholar

17. Malmgren B, Aström E, Söderhäll S. No osteonecrosis in jaws of young patients with osteogenesis imperfecta treated with bisphosphonates. J Oral Pathol Med. 2008;37:196-200.

View Article Google Scholar

18. Boonyapakorn T, Schirmer I, Reichart PA, Sturm I, Massenkeil G. Bisphosphonate-induced osteonecrosis of the jaws: prospective study of 80 patients with multiple myeloma and other malignancies. Oral Oncol. 2008;44:857-869.

View Article Google Scholar

19. Sedghizadeh PP, Stanley K, Caligiuri M, Hofkes S, Lowry B, Shuler CF. Oral bisphosphonate use and the prevalence of osteonecrosis of the jaw: an institutional inquiry. J Am Dent Assoc. 2009;140:61-66. View Article Google Scholar

20. Jeffcoat MK. Safety of oral bisphosphonates: controlled studies on alveolar bone. Int J Oral Maxillofac Implants. 2006;21:349-353.

View Article $\underline{\text { Google Scholar }}$

21. Khosla S, Burr D, Cauley J, Dempster DW, Ebeling PR, Felsenberg D, Gagel RF, Gilsanz V, Guise T, Koka S, McCauley LK, McGowan J, McKee MD, Mohla S, Pendrys DG, Raisz LG, Ruggiero SL, Shafer DM, Shum L, Silverman SL, Van Poznak CH, Watts N, Woo SB, Shane E. Bisphosphonate-associated osteonecrosis of the jaw: report of a task force of the American society for bone and mineral research. J Bone Miner Res. 2007;22:1479-1491.

View Article Google Scholar 
22. . American Association of Oral and Maxillofacial Surgeons position paper on bisphosphonaterelated osteonecrosis of the jaws. J Oral Maxillofac Surg. 2007;65:369-376.

View Article Google Scholar

23. Fedele S, Porter SR, D'Aiuto F, Aljohani S, Vescovi P, Manfredi M, Arduino PG, Broccoletti R, Musciotto A, Di Fede O, Lazarovici TS, Campisi G, Yarom N. Nonexposed variant of bisphosphonate-associated osteonecrosis of the jaw: a case series. Am J Med. 2010;123:1060-1064.

View Article Google Scholar

24. Lazarovici TS, Yahalom R, Taicher S, Elad S, Hardan I, Yarom N. Bisphosphonate-related osteonecrosis of the jaws: a single-center study of 101 patients. J Oral Maxillofac Surg. 2009;67:850-855.

View Article Google Scholar

25. Liekens S, De Clercq E, Neyts J. Angiogenesis: regulators and clinical applications. Biochem Pharmacol. 2001;61:253-270.

View Article Google Scholar

26. Wehrhan F, Stockmann P, Nkenke E, Schlegel KA, Guentsch A, Wehrhan T, Neukam FW, Amann K. Differential impairment of vascularization and angiogenesis in bisphosphonate-associated osteonecrosis of the jaw-related mucoperiosteal tissue. Oral Surg Oral Med Oral Pathol Oral Radiol Endod. 2011;112:216-221.

View Article Google Scholar

27. Di Salvatore M, Orlandi A, Bagalà C, Quirino M, Cassano A, Astone A, Barone C. Anti-tumour and antiangiogenetic effects of zoledronic acid on human non-small-cell lung cancer cell line. Cell Prolif. 2011;44:139-146.

View Article Google Scholar

28. Ferretti G, Fabi A, Carlini P, Papaldo P, Cordiali Fei P, Di Cosimo S, Salesi N, Giannarelli D, Alimonti A, Di Cocco B, D'Agosto G, Bordignon V, Trento E, Cognetti F. Zoledronic-acid-induced circulating level modifications of angiogenic factors, metalloproteinases and proinflammatory cytokines in metastatic breast cancer patients. Oncology. 2005;69:35-43.

View Article Google Scholar

29. Santini D, Vincenzi B, Avvisati G, Dicuonzo G, Battistoni F, Gavasci M, Salerno A, Denaro V, Tonini G. Pamidronate induces modifications of circulating angiogenetic factors in cancer patients. Clin Cancer Res. 2002;8:1080-1084.

View Article Google Scholar

30. Oteri G, Allegra A, Bellomo G, Alonci A, Nastro E, Penna G, Catalfamo L, Cicciù D, De Ponte FS, Musolino C. Reduced serum levels of Interleukin 17 in patients with osteonecrosis of the jaw and in multiple myeloma subjects after bisphosphonates administration. Cytokine. 2008;43:103-104.

View Article Google Scholar

31. Ribatti D, Maruotti N, Nico B, Longo V, Mangieri D, Vacca A, Cantatore FP. Clodronate inhibits angiogenesis in vitro and in vivo. Oncol Rep. 2008;19:1109-1112.

View Article Google Scholar

32. Hasmim M, Bieler G, Rüegg C. Zoledronate inhibits endothelial cell adhesion, migration and survival through the suppression of multiple, prenylation-dependent signaling pathways. J Thromb Haemost. 2007;5:166-173.

View Article Google Scholar

33. Wood J, Bonjean K, Ruetz S, Bellahcène A, Devy L, Foidart JM, Castronovo V, Green JR. Novel antiangiogenic effects of the bisphosphonate compound zoledronic acid. J Pharmacol Exp Ther. 2002;302:1055-1061.

View Article Google Scholar

34. Tang X Zhang Q Shi S Yen Y Li X Zhang Y Zhou K Le AD Bisphosphonates suppress insulin-like growth factor 1-induced angiogenesis via the HIF-1alpha/VEGF signaling pathways in human breast cancer cells Int J Cancer 2010126901032784023 10.1002/ijc.24710 
35. Yamada J, Tsuno NH, Kitayama J, Tsuchiya T, Yoneyama S, Asakage M, Okaji Y, Shuno Y, Nishikawa T, Tanaka J, Takahashi K, Nagawa H. Anti-angiogenic property of zoledronic acid by inhibition of endothelial progenitor cell differentiation. J Surg Res. 2009;151:115-120.

View Article Google Scholar

36. Fisher JE Rogers MJ Halasy JM Luckman SP Hughes DE Masarachia PJ Wesolowski G Russell RG Rodan GA Reszka AA Alendronate mechanism of action: geranylgeraniol, an intermediate in the mevalonate pathway, prevents inhibition of osteoclast formation, bone resorption, and kinase activation in vitro Proc Natl Acad Sci USA 199996133 13815105 10.1073/pnas.96.1.133

37. Shipman CM, Rogers MJ, Apperley JF, Russell RG, Croucher PI. Bisphosphonates induce apoptosis in human myeloma cell lines: a novel anti-tumour activity. Br J Haematol. 1997;98:665-672.

View Article Google Scholar

38. Kim RH Lee RS Williams D Bae S Woo J Lieberman M Oh JE Dong Q Shin KH Kang MK Park NH Bisphosphonates induce senescence in normal human oral keratinocytes J Dent Res 201190810 $816314412010.1177 / 0022034511402995$

39. Reszka AA, Halasy-Nagy J, Rodan GA. Nitrogen-bisphosphonates block retinoblastoma phosphorylation and cell growth by inhibiting the cholesterol biosynthetic pathway in a keratinocyte model for esophageal irritation. Mol Pharmacol. 2001;59:193-202.

View Article Google Scholar

40. Pabst AM, Ziebart T, Koch FP, Taylor KY, Al-Nawas B, Walter C. The influence of bisphosphonates on viability, migration, and apoptosis of human oral keratinocytes-in vitro study. Clin Oral Investig. 2012;16:87-93.

View Article Google Scholar

41. Virtanen SS, Väänänen HK, Härkönen PL, Lakkakorpi PT. Alendronate inhibits invasion of PC-3 prostate cancer cells by affecting the mevalonate pathway. Cancer Res. 2002;62:2708-2714.

View Article Google Scholar

42. Oades GM, Senaratne SG, Clarke IA, Kirby RS, Colston KW. Nitrogen containing bisphosphonates induce apoptosis and inhibit the mevalonate pathway, impairing Ras membrane localization in prostate cancer cells. J Urol. 2003;170:246-252.

View Article Google Scholar

43. Suri S, Mönkkönen J, Taskinen M, Pesonen J, Blank MA, Phipps RJ, Rogers MJ. Nitrogen-containing bisphosphonates induce apoptosis of Caco- 2 cells in vitro by inhibiting the mevalonate pathway: a model of bisphosphonate-induced gastrointestinal toxicity. Bone. 2001;29:336-343.

View Article Google Scholar

44. Scheller EL Baldwin CM Kuo S D'Silva NJ Feinberg SE Krebsbach PH Edwards PC Bisphosphonates inhibit expression of p63 by oral keratinocytes J Dent Res 201190894 8993318057 10.1177/0022034511407918

45. Allam E Allen M Chu TM Windsor LJ In vivo effects of zoledronic acid on oral mucosal epithelial cells Oral Dis 2011172912973010441 10.1111/j.1601-0825.2010.01739.x

46. Cozin M Pinker BM Solemani K Zuniga JM Dadaian SC Cremers S Landesberg R Raghavan S Novel therapy to reverse the cellular effects of bisphosphonates on primary human oral fibroblasts $\mathbf{J}$ Oral Maxillofac Surg 201169256425783179815 10.1016/j.joms.2011.03.005

47. Ziebart T, Koch F, Klein MO, Guth J, Adler J, Pabst A, Al-Nawas B, Walter C. Geranylgeraniol - a new potential therapeutic approach to bisphosphonate associated osteonecrosis of the jaw. Oral Oncol. 2011;47:195-201.

View Article Google Scholar 